\title{
INQUIRY METHOD ANALYSIS IN PROCESS LEARNING OF PEOPLE'S POETRY
}

\author{
Citra Amelia Sudiyati ${ }^{1}$, Jingga $^{2}$, Deby Luriawati ${ }^{3}$, Haryadi $^{4}$ \\ ${ }^{1,2,3,4}$ Program Studi Pendidikan Bahasa Indonesia, Pascasarjana \\ Universitas Negeri Semarang
}

Corresponding Author: ${ }^{1}$ citraamelia94@gmail.com

\begin{abstract}
In an education, learning is supported by various methods, media, and learning models to improve the quality of learning. In this article, the author only focuses on one example of the method used to assist the teaching and learning process. The method is a way whose function is as a tool to achieve a goal. The better the method, the more effective the attainment of the goal. This writing aims to describe the inquiry method regarding the strengths and weaknesses in the process of learning folk poetry and the reconstruction of the inquiry method in the process of learning folk poetry. This writing is a non-research scientific article, where only the author's ideas are expressed. Compiled from several theories such as learning folk poetry, learning methods, learning methods in the 2013 curriculum, and related to inquiry learning methods. The results of this paper are found the weaknesses and strengths of the inquiry method in learning poetry and the weaknesses are reconstructed to make it better or more effective.
\end{abstract}

Keywords: inquiry method, weaknesses, strengths, reconstruction

\section{ANALISIS METODE INKUIRI DALAM PROSES PEMBELAJARAN PUISI RAKYAT}

\begin{abstract}
Abstrak
Dalam sebuah pendidikan, pembelajaran didukung dengan berbagai metode, media, dan model pembelajaran guna meningkatkan kualitas belajar. Pada artikel ini, penulis hanya fokus pada salah satu contoh metode yang digunakan untuk membantu proses belajar mengajar. Metode merupakan cara yang fungsinya sebagai alat untuk mencapai tujuan. Makin baik metode itu, makin efektif pula pencapaian tujuan. Penulisan ini bertujuan untuk mendeskripsikan metode inkuiri terkait kelebihan dan kelemahan dalam proses pembelajaran puisi rakyat serta rekonstruksi metode inkuiri dalam proses pembelajaran puisi rakyat. Penulisan ini merupakan sebuah artikel ilmiah non-penelitian, dimana hanya diungkapkan gagasan penulis. Disusun dari beberapa teori seperti pembelajaran puisi rakyat, metode pembelajaran, metode pembelajaran dalam kurikulum 2013, dan terkait metode pembelajaran inkuiri. Hasil penulisan ini yaitu ditemukan kelemahan dan kelebihan dari metode inkuiri dalam pembelajaran puisi rayat serta dari kelemahan tersebut direskonstruksi agar menjadi lebih baik atau efektif.
\end{abstract}

Kata kunci: metode inkuiri, kelemahan, kelebihan, rekonstruksi

\section{PENDAHULUAN}

Pendidikan merupakan suatu proses yang berkesinambungan dan memiliki tujuan yang pasti untuk dicapai. Bidang pendidikan memang menjadi tumpuan harapan bagi peningkatan kualitas sumber daya manusia (SDM) agar mereka memiliki kemampuan berpikir secara kritis, logis, sistematis, kreatif, akurat, dan cermat, sehingga mampu menghadapi berbagai tantangan dalam kehidupan secara mandiri dan percaya diri (Putri, dkk., 2014).

Di era saat ini, kemajuan pada aspek seperti ekonomi, sosial, budaya, dan juga berpengaruh dalam dunia pendidikan. Dalam bidang pendidikan, guru harus dapat mengimbangi adanya 
perkembangan ilmu, pengetahuan, teknologi, dan seni (Ipteks). Guru memiliki peran penting dalam pengembangan Ipteks. Peran guru adalah sebagai pendidik, pengajar, dan motivator bagi para siswanya untuk mengembangkan diri dengan memanfaatkan kemajuan era revolusi industri (Arifah).

Pada pembelajaran puisi rakyat, guru pun memiliki peran strategis agar siswa dapat menguasai materi. Dalam dunia pendidikan terjadi perubahan kurikulum yang tadinya menggunakan kurikulum KTSP menjadi kurikulum 2013. Dengan adanya perubahan kurikulum ini, bagi siswa SMP puisi rakyat merupakan hal yang baru karena materi tersebut tidak terdapat dalam KTSP. Kerena pembahasan puisi rakyat merupakan hal yang baru seiring dengan berubahnya kurikulum, guru dan peserta didik pun masih perlu mempelajari materinya. Pemahaman guru secara sekilas mengenai pembahasan ini adalah mereka membandingkan antara puisi rakyat dengan puisi lama seperti pembagian genre puisi pada buku-buku sastra. Namun sebenarnya puisi rakyat dalam kurikulum 2013 hanyalah puisi yang terdiri atas pantun, syair, dan gurindam saja. Oleh karena itu, guru masih perlu mencoba melakukan berbagai inovasi dalam pembelajarannya.

Inovasi pembelajaran adalah salah satu kunci dalam menghadapi era revolusi industri di bidang pendidikan. Inovasi tersebut dapat didukung dengan berbagai metode, media, dan model pembelajaran guna meningkatkan kualitas belajar. Pada makalah ini, penulis akan fokus pada salah satu contoh metode yang digunakan untuk membantu proses belajar mengajar. Metode merupakan cara yang fungsinya sebagai alat untuk mencapai tujuan. Makin baik metode itu, makin efektif pula pencapaian tujuan. Dalam hal metode mengajar, faktor tujuan, peserta didik, situasi, fasilitas, dan faktor pendidik dapat menentukan efektif tidaknya penggunaan suatu metode. Karenanya metode mengajar itu banyak sekali dan sulit untuk memilihnya (Mahmudah, 2016). Namun demikian, ada sifat-sifat umum yang berbeda diantara metode yang satu dengan metode yang lain. Dengan mencari ciri-ciri umum itu, menjadi mungkinlah untuk mengenali berbagai macam metode yang lazim dan praktis untuk dilaksanakan dalam proses belajar mengajar.

Penulisan ini bertujuan untuk mendeskripsikan metode inkuiri, kelebihan dan kelemahan dalam proses pembelajaran puisi rakyat, serta rekonstruksi metode inkuiri dalam proses pembelajaran puisi rakyat.

Secara teoretis penulisan ini diharapkan dapat memberikan manfaat terhadap perkembangan dari teori terkait metode inkuiri dalam hal pembelajaran. Sedangkan secara praktis, penulisan ini diharapkan dapat dijadikan sebagai bahan untuk semakin memperkenalkan metode inkuiri yang digunakan untuk membantu proses pembelajaran dan diharapkan dapat membantu pembaca untuk memperkaya ilmu serta penulisan ini juga dapat menjadi sumbangan pemikiran terhadap penulisan yang sudah ada mengenai metode inkuiri, sehingga dapat dijadikan referensi. Kemudian, penulisan ini juga dapat memberikan kontribusi dalam hal pemahaman terkait salah satu metode pembelajaran yaitu metode inkuiri dan juga dapat dijadikan bahan pertimbangan untuk landasan kajian penulisan sejenis lainnya. 
Jurnal DISASTRI (Pendidikan Bahasa dan Sastra Indonesia)

Volume 3, Nomor 2, Agustus 2021| P-ISSN : 2716-4114 | E-ISSN: 2722-3329

\section{Pembelajaran Puisi Rakyat}

Dalam kurikulum 2013 jenjang SMP dipaparkan pada kompetensi dasar tentang pembelajaran puisi rakyat. Kompetensi dasar tentang puisi rakyat termuat dalam KD 3.13 dan 4.13. Pada KD 3.13 peserta didik diharapkan dapat mengidentifikasi informasi (pesan, rima, dan pilihan kata) dari puisi rakyat (pantun, syair, dan bentuk puisi rakyat setempat) yang dibaca dan didengar. Adapun puisi rakyat yang dimaksud berupa pantun, syair, dan puisi rakyat setempat (gurindam). Puisi diperoleh melalui proses membaca dan mendengarkan. Selain itu pembelajaran puisi rakyat juga terdapat dalam KD 4.13 yaitu menyimpulkan isi puisi rakyat. Puisi rakyat disediakan dalam bentuk tulis kemudian siswa diminta untuk menarik kesimpulan.

Pembelajaran sastra khususnya puisi dalam kurikulum 2013 bertujuan mengikutsertakan peserta didik untuk terlibat dalam pengkajian tentang nilai kepribadian, budaya, sosial, dan estetik. Dalam pembelajaran, karya sastra dipilih dengan ketentuan memiliki potensi untuk memperkaya kehidupan peserta didik, pengalaman kejiwaan, dan mengembangkan imajinasi peserta didik. Dalam kurikulun KTSP pembelajaran mengutamakan sisi komunikatifnya, namun pada kurikulum 2013 pembelajaran bahasa Indonesia lebih mengedepankan komunikatif dan fungsi sosialnya.

\section{Metode Pembelajaran}

Menurut Hamdani (2011:80), metode pembelajaran adalah cara yang digunakan pendidik untuk menyampaikan pelajaran kepada peserta didik. Menurut Kamus Besar Bahasa Indonesia, yang pertama, Metode merupakan cara kerja yang bersistem untuk memudahkan pelaksanaan suatu kegiatan guna mencapai tujuan yang ditentukan. Yang kedua, metode merupakan upaya yang digunakan utuk mengimplementasikan rencana yang sudah disusun dalam kegiatan nyata untuk mencapai tujuan pembelajaran. Pengertian lain mengenai metode diungkapkan oleh Dewi (2018:48) yang mengungkapkan bahwa metode merupakan alat untuk mengembangkan proses belajar mengajar guna menunjang pencapain hasil belajar.

Menurut penjelasan di atas tersebut, metode pembelajaran berarti cara yang digunakan oleh pendidik untuk mempersiapkan segala hal yang dipersiapkan untuk kebutuhan belajar mengajar agar sesuai dengan tujuan yang ingin dicapai. Setelah pengertian ada beberapa karakteristik metode pembelajaran, diantaranya adalah:

1. Memungkinkan terciptanya kondisi kondusif selama proses pembelajaran.

2. Memberikan kemudahan bagi peserta didik dalam mempelajari bahan ajar selama proses pembelajaran.

3. Memotivasi peserta didik untuk berpartisipasi secara aktif dalam setiap kegiatan pembelajaran.

4. Memungkinkan peserta didik untuk memperoleh pengalaman belajar yang mencakup segenap potensi dalam dirinya secara seimbang.

5. Memungkinkan peserta didik untuk melakukan refleksi secara bebas terhadap pengalaman belajar yang diperoleh ketika berinteraksi dengan lingkungan sekitar (fisik dan sosial).

6. Mendorong tumbuh-kembangnya kepribadian peserta didik, utamanya sikap terbuka, demokratis, disiplin, tanggungjawab, dan toleran serta 
kmitmen terhadap nilai-nilai sosiobudaya bangsanya.

Upaya pendidik dalam memilih metode yang tepat dalam mendidik peserta didiknya harus pula disesuaikan dengan tuntutan dan karakteristik peserta didiknya. Seorang pendidik harus megusahakan agar pelajaran yang disampaikan kepada peserta didiknya mudah diterima, tidak cukup hanya dengan bersikap lembut saja.

\section{Metode Pembelajaran dalam Kurikulum 2013}

Metode pembelaran dalam kurikulum 2013 menuntut peserta untuk belajar aktif untuk memperoleh pengetahuan, keterampilan, dan sikap (Mantasia, 2018:281). Lebih lanjut, Mantasia (2018:282) menyatakan bahwa metode pembelajaran yang sesuai dengan kurikulum 2013 yaitu pendekatan ilmiah, kontekstual, berbasis masalah, berbasis proyek, kooperatif, pendekatan pembelajaran komunikatif.

Dari sini dapat dipahami bahwa metode pembelajaran dalam kurikulum 2013 harus berfokus pada peserta sebagai peneliti, dalam hal ini adalah peserta didik harus aktif menemukan jawaban secara mandiri dengan rasa keingintahuan tinggi.

\section{Metode Pembelajaran Inkuiri}

Inkuiri berasal dari bahasa Inggris yaitu inquiry yang dapat diartikan sebagai proses bertanya dan mencari tahu jawaban terhadap pertanyaan ilmiah yang diajukan. Metode inkuiri ini lebih menekankan peserta didik agar berpikir kritis dan analitis dalam pembelajaran, sehingga pembelajaran yang menurut peserta didik sulit, peserta didik harus berpikir untuk mencari dan menemukan sendiri jawaban dari masalah tersebut (Choirunisa, dkk., 2019).

Menurut Gulo (dalam Al-Tabani, 2014: 78) menyatakan metode inkuiri berarti suatu rangkaian kegatan belajar yang melibatkan secara maksimal seluruh kemampuan peserta didik untuk mencari dan menyelidiki secara sistematis, kritis, logis, analitis, sehingga mereka dapat merumuskan sendiri penemuanpenemuannya dengan penuh percaya diri.

Menurut Al-Tabani (2014: 80) pembelajaran dengan metode Inkuiri memiliki beberapa ciri-ciri, yaitu:

1. Pembelajaran inkuiri menekankan kepada aktivitas peserta didik secara maksimal untuk mencari dan menemukan.

2. Seluruh aktivitas yang dilakukan peserta didik diarahkan untuk mencari dan menemukan jawaban sendiri dari sesuatu yang dipertanyakan, sehingga diharapkan untuk dapat menumbuhkan sikap percaya diri.

3. Tujuan dari pembelajaran inkuiri yaitu mengembangkan kemampuan berfikir secara sistematis, logis, dan kritis, atau mengembangkan kemampuan intelektual sebagai bagian dari proses mental. 
Jurnal DISASTRI (Pendidikan Bahasa dan Sastra Indonesia)

Volume 3, Nomor 2, Agustus 2021| P-ISSN : 2716-4114 | E-ISSN: 2722-3329

\section{PEMBAHASAN}

\section{Kelebihan Metode Inkuiri dalam Pembelajaran Puisi Rakyat}

Sesuai dengan pengertian tersebut, pastilah metode inkuiri memiliki manfaat yang diharapkan oleh peserta didik apabila menerapkan metode tersebut. Berikut adalah kelebihan penggunaan metode inkuiri dalam pembelajaran puisi rakyat.

Menurut Hamdani (2011:182-183), karena melibatkan peserta didik secara aktif, metode ini mengandung berbagai kebaikan, yaitu: pengetahuan bertahan lama atau dapat diingat dalam waktu lama dan lebih mudah diingat apabila dibandingkan dengan pengetahuan yang dipelajari dengan cara-cara lain; hasil belajar mempunyai efek transfer yang baik daripada hasil belajar lainnya, dengan kata lain, konsep-konsep dan prinsip-prinsip yang dijadikan milik kognitif seseorang lebih mudah diterapkan pada situasisituasi baru; secara menyeluruh, meningkatkan penalaran peserta didik dan kemampuan berfikir secara bebas.

Lebih lanjut, Aqib (2013:108) menjelaskan kelebihan penggunaan metode inkuiri adalah metode inkuiri membiasakan peserta didik belajar mengidentifikasi dan memecahkan masalah serta mengambil keputusan; membiasakan peserta didik berhadapan dengan berbagai kepribadian dan interpretasi; dan membiasakan peserta didik untuk berargumentasi dan berpikir secara rasional.

Kelebihan metode inkuiri jika dijelaskan oleh AB, dkk. (2016:78-79) adalah mendorong peserta didik untuk berpikir dan atas inisiatifnya sendiri; situasi belajar menjadi lebih terangsang; dapat membentuk dan mengembangkan sel consept pada diri peserta didik; dan mendorong peserta didik berpikir intuitif dan mengembangkan hipotesisnya sendiri.

Dari beberapa rumusan kelebihan metode inkuiri tersebut dapat ditarik simpulan bahwa penggunaan metode inkuiri memiliki manfaat pada tabel sebagai berikut.

\begin{tabular}{|l|l|}
\hline No. & \multicolumn{2}{|l|}{ Kelebihan Metode Inkuiri } \\
\hline 1. & $\begin{array}{l}\text { Pengetahuan yang didapat } \\
\text { dapat diingat dalam jangka } \\
\text { waktu yang panjang. }\end{array}$ \\
\hline 2. & $\begin{array}{l}\text { Merangsang keinginan peserta } \\
\text { didik untuk belajar. }\end{array}$ \\
\hline 3. & $\begin{array}{l}\text { Membentuk daya pikir peserta } \\
\text { didik lebih rasional. }\end{array}$ \\
\hline 4. & $\begin{array}{l}\text { Mendorong dan } \\
\text { berargumentasi peserta } \\
\text { mengambil keputusan sendiri. }\end{array}$ \\
\hline 5. & $\begin{array}{l}\text { Melatih sikap sosial peserta } \\
\text { didik berhadapan dengan } \\
\text { berbagai macam kepribadian. }\end{array}$ \\
\hline
\end{tabular}

Di dalam pembelajaran mengidentifikasi informasi puisi rakyat, peserta didik dapat mencari informasinya sendiri terkait pesan, rima, dan pilihan kata yang mana dengan metode inkuiri yang befokus pada peserta didik, informasi tersebut dapat diingat dalam waktu lama. Peserta didik berusaha mencari sendiri informasi puisi rakyat dari berbagai sumber. Dengan bantuan metode inkuiri pada pembelajaran mengidentifikasi informasi puisi rakyat, peserta didik dibebaskan untuk memahami materi tersebut dengan caranya masing-masing.

\section{Kelemahan Metode Inkuiri}

Setiap metode dirancang untuk memenuhi kebutuhan karena memiliki kelebihan. Hanya saja, setiap metode pasti 
memiliki kelemahan atau kekurangan yang mendampingnya. Berikut ini adalah kekurangan metode inkuiri.

Aqib (2013:113) menyatakan bahwa metode inkuiri memiliki beberapa kelemahan yang harus diwaspadai oleh pendidik. Diantaranya adalah metode ini hanya bisa dilaksanakan apabila peserta didik sudah berada pada level kognitif yang tinggi, sehingga penerapan pada peserta didik kelas rendah dianggap akan kurang cocok dan tidak memahamkan peserta didik; menimbulkan kejenjangan pada peserta didik karena pemahaman mengikuti intepretasi peserta didik pada materi yang disajikan; menimbulkan permasalahan baru dan tidak fokus ke pokok masalah utama.

Menurut Suryobroto dalam AB, dkk. (2016:79) kelemahan dari metode inkuiri adalah dipersyaratkan oleh keharusan ada persiapan mental untuk cara belajar ini; pembelajaran inkuiri kurang berhasil dalam kelas besar, karena sebagian waktu hilang karena membantu peserta didik menemukan ejaan dari bentuk kata-kata tertentu; harapan yang diinginkan dari metode ini mengecewakan peserta didik yang biasa pada dengan perencanaan dan pembelajaran secara ekspotoris (ceramah) jika pendidik tidak menguasai pembelajaran inkuiri.

Selanjutnya, pendapat mengenai kelemahan metode inkuiri dikemukakan oleh Masyhitah, dkk. (2017:52-53) yaitu sulit mengontrol kegiatan dan keberhasilan peserta didik; sulit dalam merencanakan pembelajaran karena terbentur dengan kebiasaan peserta didik dalam belajar; memerlukan waktu yang panjang sehingga pendidik sering sulit menyesuaikan dengan waktu yang telah ditentukan; selama kriteria keberhasilan belajar ditentukan oleh kemampuan peserta didik menguasai materi pembelajaran, maka strategi ini tampaknya akan sulit diimplementasikan.

Berdasarkan beberapa kelemahan metode inkuiri tersebut dapat disimpulkan kelemahan metode inkuiri menurut penulis pada tabel berikut.

\begin{tabular}{|l|l|}
\hline No. & \multicolumn{2}{|c|}{ Kelemahan Metode Inkuiri } \\
\hline 1. & $\begin{array}{l}\text { Memerlukan waktu yang tidak } \\
\text { sedikit dalam penerapannya. }\end{array}$ \\
\hline 2. & $\begin{array}{l}\text { Timbul kesenjangan antara } \\
\text { peserta didik karena kriteria } \\
\text { keberhasilan adalah } \\
\text { kemampuan peserta didik } \\
\text { menguasai materi pembelajaran. }\end{array}$ \\
\hline 3. & $\begin{array}{l}\text { Pemecahan masalah masih akan } \\
\text { sangat abstrak kecuali pendidik } \\
\text { memahami penerapan metode } \\
\text { inkuiri dengan baik. }\end{array}$ \\
\hline 4. & $\begin{array}{l}\text { Mengecewakan peserta didik } \\
\text { yang memiliki tipe belajar } \\
\text { mendengarkan (ceramah). }\end{array}$ \\
\hline 5. & $\begin{array}{l}\text { Kurang cocok diterapkan pada } \\
\text { kelas besar karena susahnya } \\
\text { pengontrolan kegiatan peserta } \\
\text { didik. }\end{array}$ \\
\hline
\end{tabular}

Dengan metode inkuiri, untuk memahami informasi yang terdapat dalam puisi rakyat serta menyimpulkannya diperlukan waktu yang lama, karena pemahaman peserta didik yang berbedabeda, cara belajar yang berbeda, membuat setiap peserta didik memiliki penyelesaian dalam memahami materi yang berbeda. Apalagi pembelajaran hanya berfokus pada peserta didik tanpa adanya bantuan oleh pendidik sebagai penguatan materi, maka pemecahan masalah akan sangat abstrak.

\section{Rekonstruksi Metode Inkuiri dalam Pembelajaran}

Dari hasil analisis terkait kelemahan dan kelebihan metode inkuiri dalam 
pembelajaran puisi rakyat. Penulis akan merekonstruksi kelemahan dari metode inkuiri seperti yang sudah dijelaskan sebelumnya. Rekonstruksi dilakukan dengan memadukan metode inkuiri dengan metode ceramah agar lebih efektif.

1. Metode inkuiri hanya berpusat pada peserta didik

Metode inkuiri dilakukan dengan berpusat pada peserta didik, yang mana peserta didik akan lebih aktif daripada pendidik. Dalam pembelajarannya, metode inkuiri dilakukan dengan membagi peserta didik menjadi beberapa kelompok, kemudian mereka diminta mencari dan menemukan informasi serta menyimpulkan puisi rakyat, setelah itu dikomunikasikan yang mana nantinya akan ada diskusi antar peserta didik. Sebelumnya, pendidik hanya memberi tahu terkait topik yang akan dibahas yang kemudian peserta didik mempelajari sendiri.

Metode inkuiri kurang efektif jika dilakukan dalam proses pembelajaran puisi rakyat karena pada kurikulum 2013 materi puisi rakyat bertujuan mengikutsertakan peserta didik untuk terlibat dalam pengkajian tentang nilai kepribadian, budaya, sosial, dan estetik. Dalam pembelajaran, karya sastra dipilih dengan ketentuan memiliki potensi untuk memperkaya kehidupan peserta didik, pengalaman kejiwaan, dan mengembangkan imajinasi peserta didik. Dalam kurikulun KTSP pembelajaran mengutamakan sisi komunikatifnya, namun pada kurikulum 2013 pembelajaran bahasa Indonesia lebih mengedepankan komunikatif dan fungsi sosialnya. Alangkah baiknya jika metode inkuiri digabung dengan metode ceramah. Metode ceramah merupakan proses pembelajaran yang berpusat pada pendidik. Ketika pendidik dan peserta didik sama-sama menjadi objek yang penting di dalam proses belajar, maka pembelajaran akan jauh lebih efektif, pendidik dan peserta didik dapat saling bertukar informasi. Keduanya dapat saling bertukar informasi terkait puisi rakyat, sehingga dalam pembelajaran akan komunikatif dan fungsi sosial akan terjalin.

2. Metode inkuiri membutuhkan banyak waktu

Setiap manusia memiliki kemampuan berpikir yang berbeda. Ada yang cepat tanggap, ada yang harus memahami berulang-ulang. Ketika metode inkuiri diterapkan di dalam pembelajaran puisi rakyat, akan membutuhkan banyak waktu untuk peserta didik dapat memahami materi yang diinginkan oleh pendidik. Hal tersebut terjadi karena setiap peserta didik memiliki kemampuan berpikir berbeda-beda. Jika seorang pendidik mengharuskan untuk semua peserta didik paham terkait materi yang diinginkannya, maka jika metode inkuiri dilaksanakan akan membutuhkan banyak waktu, apalagi untuk dapat menyimpulkan informasi dari puisi rakyat memerlukan pemahaman yang sungguh-sungguh. Sehingga lebih baik metode tersebut digabung dengan metode ceramah yang mana pendidik ikut berperan aktif dalam pembelajaran. Peserta didik yang masih kurang paham dapat bertanya pada pendidik, kemudian pendidik menjelaskan secara detail agar peserta didik memahaminya. Hal tersebut dapat mengeefektifkan waktu pembelajaran.

3. Cara belajar peserta didik berbeda Setiap peserta didik memiliki kemampuan yang berbeda-beda untuk memeroleh pengetahuan. Ada yang 
dengan cara membaca dan juga ada yang dengan menyimak atau mendengarkan. Ketika metode inkuiri dilaksanakan dalam pembelajaran puisi rakyat, maka peserta didik harus siap untuk mencari informasinya sendiri, kemudian berusaha memecahkan sendiri jika ditemukan masalah. Tetapi hal tersebut tidak dapat dilakukan oleh peserta didik yang memiliki kemampuan menangkap informasi melalui menyimak. Sehingga, ketika metode inkuiri dilaksanakan, pendidik seharusnya menggabungkannya dengan metode lain yang dapat saling melengkapi. Dengan hal itu, tidak ada peserta didik yang tertinggal materi.

Dari penjelasan di atas, dalam proses belajar mengajar, akan lebih baik jika dilakukan dengan lebih dari satu metode. Metode inkuiri dapat disandingkan dengan metode ceramah, yang mana metode ceramah berpusat pada pendidik yang memberikan materinya kepada peserta didik, kemudian setelah metode ceramah dilakukan, pendidik melanjutkan dengan metode inkuiri, yaitu peserta didik diharuskan untuk mencari dan menemukan sendiri informasi yang telah diberikan oleh pendidik. Dalam proses belajar tidak hanya menerima melalui metode ceramah yang dilakukan pendidik, melainkan juga menemukan sendiri inti dari materi atau dilakukan metode inkuiri. Jika kedua metode tersebut dapat terlaksana dengan baik, maka proses belajar mengajar pun tidak memerlukan waktu yang lama dan pastinya akan lebih efektif.

\section{PENUTUP}

Setiap metode yang digunakan dalam pembelajaran pasti tidak semua berjalan lancar, seperti metode inkuiri yang memiliki kelebihan maupun kekurangan dalam pelaksanaannya. Kelebihan metode inkuiri yaitu pengetahuan yang didapat dapat diingat dalam jangka waktu panjang, merangsang keinginan peserta didik untuk belajar, membentuk daya pikir peserta didik lebih rasional, mendorong peserta didik berargumentasi dan mengambil keputusan sendiri, serta melatih sikap sosial peserta didik berhadapan dengan berbagai macam kepribadian. Kemudian kelemahan dari metode inkuiri yaitu memerlukan waktu yang lama dalam penerapannya, timbul kesenjangan antar peserta didik karena kriteria keberhasilan adalah kemampuan peserta menguasai materi pembelajaran, pemecahan masalah masih sangat abstrak, mengecewakan peserta didik yang memiliki tipe belajar mendengarkan, dan kurang cocok diterapkan pada kelas besar karena sulis untuk mengontrolnya.

Dari beberapa kelemahan yang sudah dijelaskan, maka sebaiknya dilakukan rekonstruksi agar dari kelemahan tersebut dapat ditemukan solusinya. Pada pelaksanaannya, metode inkuiri akan memakan banyak waktu dan jika kurang terarah, pembelajaran akan menjadi kacau dan kekaburan atas materi yang dipelajari. Sehingga dalam proses belajar mengajar, akan lebih baik jika dilakukan dengan lebih dari satu metode. Metode inkuiri dapat disandingkan dengan metode ceramah, yang mana metode ceramah berpusat pada pendidik yang memberikan materinya kepada peserta didik, kemudian setelah metode ceramah dilakukan, pendidik melanjutkan dengan metode inkuiri, yaitu peserta didik diharuskan untuk mencari dan menemukan sendiri informasi yang telah diberikan oleh pendidik. 
Jurnal DISASTRI (Pendidikan Bahasa dan Sastra Indonesia)

Volume 3, Nomor 2, Agustus 2021| P-ISSN : 2716-4114 | E-ISSN: 2722-3329

\section{DAFTAR PUSTAKA}

Agustina, Eka Sofia. (2013). Pembelajaran Bahasa Indonesia Berbasis Teks: Representasi Kurikulum 2013. AKSARA: Jurnal Bahasa dan Sastra Vol. 18, No. 1, Hal. $84 \pm$ 99, April 2017

Aqib, Zainal. (2013). Model-Model, Media, dan Strategi Pembelajaran Kontekstual (Inovatif). Bandung: Yrama Media.

Arifah, Zaidatul. Inovasi Pembelajaran Puisi Rakyat Pada Peserta Didik Smp Di Era Revolusi Industri 4.0.

Arifien, Helpy Patriana dan Suniati . 2018. Peningkatan Hasil Belajar Bahasa Indonesia Menggunakan Metode Inkuiri Dengan Media Konkret Pada Peserta Didik Palangkaraya. Tunas Jurnal Pendidikan Guru Sekolah Dasar. Volume 4 Nomor 1.

Arikunto, Suharsimi. (2002). Prosedur Penelitian Kualitatif. Jakarta: Rineka Cipta.

Bungin, Burhan. (2003). Analisis Penelitian Kualitatif. Jakarta: Grafindo Persada Choirunisa, Ade, Dilla Fadhillah, dan Hamdah Siti Hamsanah Fitriani. 2019. Pengaruh Metode Inkuiri Terhadap Kemampuan Membaca Intensif Pada Pembelajaran Bahasa Indonesia Siswa Kelas Iv Sdn Jurumudi 3 Kecamatan Benda Kota Tangerang. Indonesian Journal of Elementary Education. Vol.1 No.1.

Hamdani. (2011). Strategi Pembelajaran. Bandung: Pustaka Setia.

Huda, Fatkhan Amirul. 2018. Pengertian dan Langkah-Langkah Model Pembelajaran Inkuiri. https://fatkhan.web.id/pengertiandan-langkah-langkah-modelpembelajaran-inkuiri-inkuirilearning/. Diakses pada 8 April 2021 pukul 21.00.
Mahmudah, Masruroh. 2016. Urgensi Diantara Dualisme Metode Pembelajaran Ceramah Dalam Kegiatan Belajar Mengajar Untuk Siswa Mi/Sd. Cakrawala. Vol. XI, No. 1.

Mahsun. (2014). Pembelajaran Bahasa Indonesia dalam Kurikulum 2013. Jakarta: Grafindo Persada.

Malik, Abdul, Chandra Ertikanto, dan Agus Suyatna. 2015. Deskripsi Kebutuhan Hots Assessment Pada Pembelajaran Fisika Dengan Metode Inkuiri Terbimbing. Prosiding Seminar Nasional Fisika (E-Journal) SNF2015. Volume IV. Moleong, L,.J. (2007). Metode Penelitian Kualitatif. Bandung: Remaja Rosdakarya. Putri, Cahyani Ari, Semara Putra, dan Siti Zulaikha. 2014. Pengaruh Metode Pembelajaran SQ3R Terhadap Hasil Belajar Bahasa Indonesia Kelas V SD. Jurnal Mimbar PGSD Universitas Pendidikan Ganesha Jurusan PGSD. Vol. 2 No. 1.

Ranabumi, Raditya, Muhammad Rohmadi, dan Slamet Subiyantoro. 2017. Penggunaan Metode Ceramah Dalam Pembelajaran Menulis Teks Eksposisi Pada Siswa Kelas VII-B SMP Negeri 5 Kediri. The 1st Education And Language International Conference Proceedings Center For International Language Development Of Unissula . ELIC 2017.

Sani, Ridwan Abdullah. (2014). Pembelajaran Saintifik untuk Implementasi Kurikulum 2013. Bumi Aksara: Jakarta

Shafa. (2014). Karakteristik Proses Pembelajaran Kurikulum 2013. 
Dinamika: Jurnal Dinamika Vol. 14 no. 1 juni 2014.

Sugiyono, M. P. P. (2007). Pendekatan Kuantitatif. Kualitatif, dan R\&D. Bandung: Alfabeta.

Umami, Risa, Marungkil Pasaribu, dan Amran Rede. Penerapan Metode Inkuiri Untuk Meningkatkan Hasil Belajar IPA Siswa Kelas IV SD Inpres Bajawali Kecamatan Lariang Kabupaten Mamuju Utara. Jurnal Kreatif Tadulako Online. Vol. 3 No. 2 